\title{
Effect of habitat heterogeneity in the composition and distribution of Chironomidae (Diptera) assemblage in different microhabitats of preserved streams in the Brazilian Atlantic Forest
}

Efeito da heterogeneidade de habitat na composição e distribuição da assembleia de Chironomidae (Diptera) em diferentes microhabitats de riachos preservados da Mata Atlântica Brasileira

Fernanda de Almeida Gurski ${ }^{1}$, Gisele Daiane Pinha ${ }^{2}$, Yara Moretto ${ }^{3}$, Alice Michiyo Takeda ${ }^{4}$ and Norma Catarina Bueno ${ }^{5}$

${ }^{1}$ Programa de Pós-Graduação em Recursos Pesqueiros e Engenharia de Pesca, Universidade Estadual do Oeste do Paraná - Unioeste, Rua da Faculdade, 645, Jardim Santa Maria,

CP 320, CEP 85903-000, Toledo, PR, Brazil

e-mail: fer_gurski@yahoo.com.br

${ }^{2}$ Programa de Pós-Graduação em Ecologia de Ambientes Aquáticos Continentais,

Universidade Estadual de Maringá - UEM, Av. Colombo, 5790. CEP 87020-900, Maringá, PR, Brazil e-mail: gipinha@yahoo.com.br

${ }^{3}$ Laboratório de Ecologia, Pesca e Ictiologia (LEPI), Programa de Pós-Graduação em Aquicultura e

Desenvolvimento Sustentável, Setor Palotina, Universidade Federal do Paraná - UFPR,

Rua Pioneiro, 2153, Jd. Dallas, CEP 85490-000, Palotina, PR, Brazil

e-mail: yara.moretto@gmail.com

${ }^{4}$ Programa de Pós-Graduação em Ecologia de Ambientes Aquáticos - PEA, Núcleo de Pesquisa em

Limnologia, Ictiologia e Aquicultura - NUPELIA, Departamento de Biologia - DBI,

Universidade Estadual de Maringá - UEM, Av. Colombo, 5790, CEP 87020-900, Maringá, PR, Brazil e-mail: alicemtakeda@yahoo.com.br

${ }^{5}$ Centro de Ciências Biológicas e da Saúde - CCBS, Universidade Estadual do Oeste do Paraná - Unioeste, Rua Universitária, 1619, Jd. Universitário, CP 701, CEP 85819-110, Cascavel, PR, Brazil e-mail:normacatarina@hotmail.com

\begin{abstract}
Aim: This study aimed at to evaluate the influence of habitat heterogeneity on the attributes of richness, abundance, diversity and equitability of Chironomidae assemblage and also the biological differences in faunistic composition related to each microhabitat. Methods: The sampling was performed in summer (February) and winter (August) 2010, with Surber sampler, in three headwaters streams at Atlantic Forest, in southern Brazil. Results: In the total 6,429 Chironomidae larvae were identified and classified into 96 taxa belonging to Chironominae, Tanypodinae and Ortocladiinae subfamilies. Among the microhabitats, the highest richness was observed in the deposits of litter, and the highest number of exclusive species took place in the pool regions. Conclusions: Thus, the composition and structure of the Chironomidae assemblage are directly related to the availability and heterogeneity of habitats in streams.
\end{abstract}

Keywords: substrate, microhabitat, conservation unit, benthic invertebrates, richness.

Resumo: Objetivo: Este trabalho teve como objetivo avaliar a influência da heterogeneidade de habitats sobre os atributos de riqueza, abundância, diversidade e equitabilidade da assembleia de Chironomidae e também as diferenças biológicas na composição faunística relacionada a cada microhabitat. Métodos: As coletas foram realizadas no verão (fevereiro) e inverno (agosto) de 2010, com um amostrador tipo Surber. Resultados: As variáveis ambientais analisadas não foram significativamente diferentes entre os riachos amostrados, porém a riqueza taxonômica de larvas de Chironomidae foi distinta entre os microhabitats. Foram identificadas 6.469 larvas de Chironomidae distribuídas em 96 táxons pertencentes às subfamílias Chironominae, Tanypodinae e Ortocladiinae. Entre os microhabitats, a maior riqueza foi observada nos depósitos de folhiços em locais de remanso, onde também foram registrados os maiores números de espécies exclusivas. Conclusóes: Portanto, a composição e estrutura da assembleia de Chironomidae estáo diretamente relacionadas à heterogeneidade de habitats disponíveis nos riachos.

Palavras-chave: substrato, microhabitat, unidade de conservação, invertebrados bentônicos, riqueza. 


\section{Introduction}

Benthic invertebrates are essential to the transformation of organic matter and nutrient cycling in aquatic environments (Graça, 2001; Devine and Vanni, 2002). The community represents an important component for the understanding of both structure and functioning of aquatic communities, as well as the ecological processes related to hydrological variations (Vannote et al., 1980). Several authors have studied the composition and distribution of benthic invertebrate assemblages searching for a better understanding of the natural structures of aquatic ecosystems and their biotic and abiotic relationships (Vannote et al., 1980; Ferrington-Junior, 1984; Rae, 2004; Inoue et al., 2005).

Among the benthic macroinvertebrates, the Chironomidae larvae is one the most abundant and diverse species in many aquatic environments, due to its adaptive strategy and diversity of feeding habits, making it an essential part of nutrient cycling within those ecosystems (Pinder, 1986; Cranston, 1995; Ferrington-Junior, 2008,). The distribution and composition of Chironomidae assemblages is related to the type of substrate, flow dynamics, water temperature and availability of organic matter of streams (Pinder, 1986; Berg, 1995; Sanseverino et al., 1998; Henriques-Oliveira et al., 2003; Amorim et al., 2004; Pinha, et al., 2013). Moreover, the group is affected by physical and chemical variables as a result of the different stages of organic matter decomposition, depending on both lotic site and microhabitat (Biasi et al., 2013).

There is a great substrate heterogeneity in headwater streams promoted by their source elements, such as allochthonous organic matter and rocks (Allan and Castillo, 2007). The substrate heterogeneity promotes a high diversity of microhabitats related to their distribution along the stream, to changes related to internal processes (cycling nutrients, moving bodies) and to external influences (Weatherproof, climatic and seasonal changes, etc.). In general, microhabitat diversity influences the invertebrate fauna, which increases habitat heterogeneity proportionally (Brown, 2007; Raio et al., 2011).

Related investigations show that a higher substrate heterogeneity and complexity increases richness and diversity of Chironomidae assemblage. Availability of shelter, protection, site for nidation along part or the entire life cycle and a rich epiphytic flora as well as other organic material for feeding provided by these environments were the main influencing factors determined by the authors (Callisto et al., 2007; Sanseverino and Nessimian, 2008; Silveira et al., 2013; König and Santos, 2013).

In this way, the present study aimed to evaluate the influence of habitat heterogeneity on the attributes of richness, density, diversity and evenness of Chironomidae assemblage and the biological differences in the faunistic composition related to each microhabitat.

Therefore, it was hypothesized that there will be an increase in richness, diversity and abundance of Chironomidae larvae attributes, especially in areas with rapids and in litter microhabitats. The amount of organic litter may offer more stability and anchorage places for the larvae, that together with stream flow increases the suspension food, also bringing nutrients and organisms. Further, due to the pristine characteristic of the environments we expect a higher quantity of rare or uncommon species in the microhabitat.

\section{Material and Methods}

\subsection{Study area}

The Iguaçu National Park $\left(25^{\circ} 05^{\prime}\right.$ to $25^{\circ} 41^{\prime}$ $S$ and $53^{\circ} 40^{\prime}$ to $\left.54^{\circ} 38^{\prime} \mathrm{W}\right)$, located in the Western Paraná State, is a Conservation Unit that compounds one of the rare continuous and preserved areas of Atlantic Forest of interior, in Southern Brazil, considered to be one a biodiversity hotspot (Rylands and Brandow, 2005). The rivers, both entirely and partially protected by the boundaries of this unit (Figure 1), are references for the structure of aquatic ecosystem of this biome. The sampling region's climate is mild mesothermal and super humid, without droughts and potential occurrence of flooding throughout the year. Mean annual temperatures range between 18 and $20^{\circ} \mathrm{C}$, with an absolute maximum between 34 to $36^{\circ} \mathrm{C}$, and a minimum range of -8 to $-4^{\circ} \mathrm{C}$. The level of annual rainfall lies between 1,500 and $1,750 \mathrm{~mm}$.

\subsection{Data collection}

Sampling was conducted during summer (February) and winter (August) of 2010 using Surber sampler $\left(0.04 \mathrm{~m}^{2}\right)$, with a mesh size of $200 \mu \mathrm{m}$ in two sites of the three streams. At each site, triplicate substrate samples were taken from four different microhabitats for biological analyses, further one sample for granulometric texture analysis which resulted in 26 samples per stream.

The established microhabitats were denominated as followed: litter pool (PL, deposit of leaves at sites with little or no flow, near the banks), litter riffle 


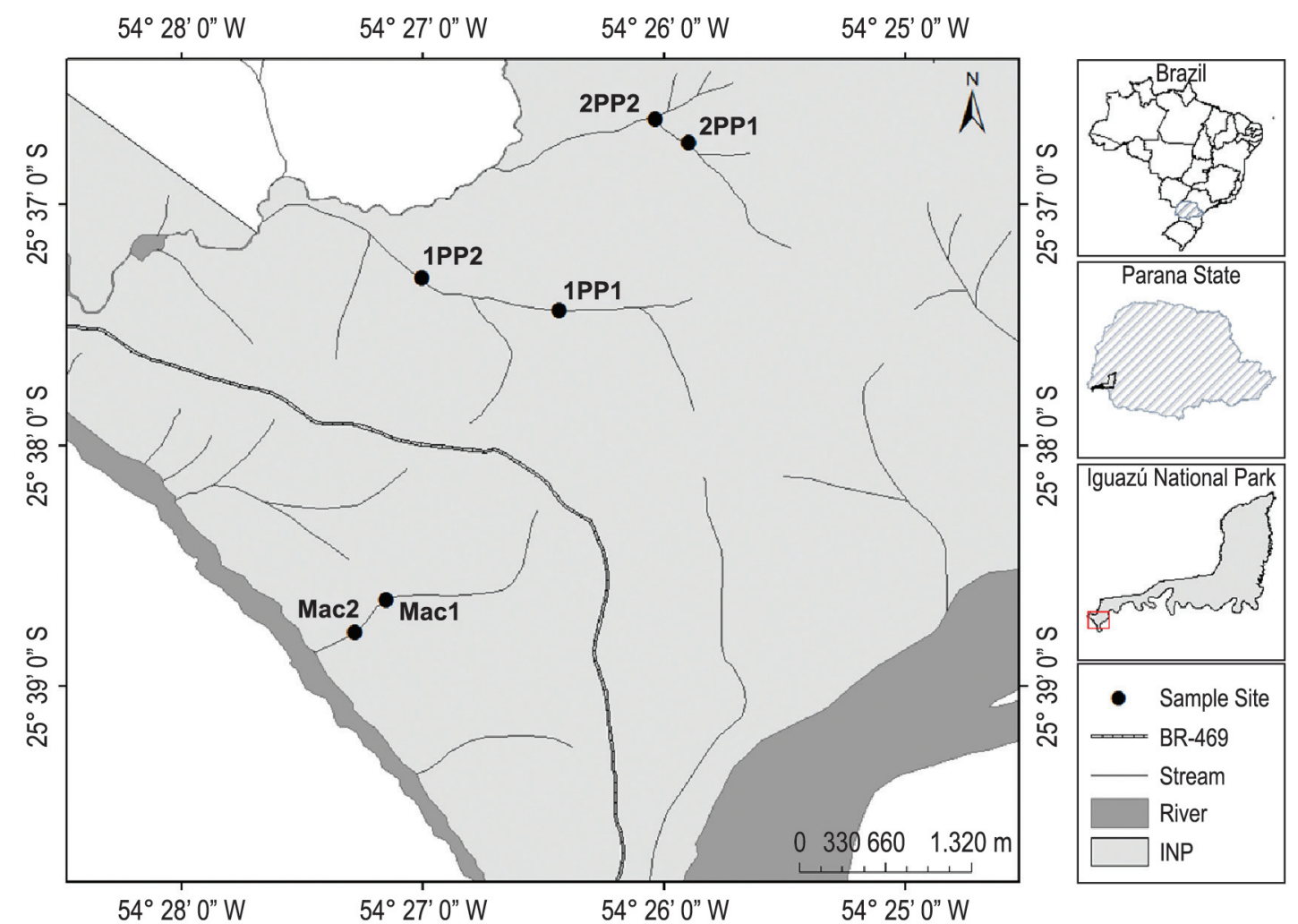

Figure 1. Location of the sampling sites in the Iguaçu National Park (INP). Mac1: stream of Macuco site 1; Mac2: stream of Macuco site 2; 1PP1: stream 1 of Poço Preto site 1; 1PP2: stream 1 of Poço Preto site 2; 2PP1: stream 2 of Poço Preto site 1; 2PP2A: stream 2 of Poço Preto site 2.

(RL, deposit of leaves retained in areas with rapids), substrate pool (PS, deposit of sediments at sites with little or no flow, near the banks) and substrate riffle (RS, sediments and material attached or deposited on rocks located in areas with rapids).

Concomitantly to sediment samplings, values of water temperature $\left({ }^{\circ} \mathrm{C}\right)$, dissolved oxygen concentration (Microprocessor Oximeter AT 150), $\mathrm{pH}$ ( $\mathrm{pHmeter}$ AT -300 ), electric conductivity (portable conductivimeter), flow $\left(\mathrm{m} . \mathrm{s}^{-1}\right)$ (river width $\mathrm{x}$ average depth $\mathrm{x}$ average speed of the flow), width $(\mathrm{m})$ and depth $(\mathrm{m})$ were measured.

After sampling, the sediment for biological analysis was cleaned under running water using a set of sieves with different mesh sizes $(2.0,1.0$, and $0.2 \mathrm{~mm}$ ). The material retained in the last mesh was placed in polyethylene bottles with $70 \%$ alcohol for further sorting under stereoscopic microscopes and identified to the lowest taxonomic level possible, with optical microscope (with increased of 400x and 1000x). The taxonomy was realized according to Epler (2001), Trivinho-Strixino and Strixino (1995) and Trivinho-Strixino (2011).

Sediment samples for granulometric texture analysis were oven dried at $80^{\circ} \mathrm{C}$, grain texture was determined according to Wentworth scale described by Suguio (1973). The percentage of organic matter of the sediment was determined by the calcination of samples for 4 hours in a muffle furnace at $540^{\circ} \mathrm{C}$, for determination of coarse particulate organic matter percentage $(\mathrm{CPOM}-$ particles $>1 \mathrm{~mm})$ and fine particulate organic matter (FPOM - particles $<1 \mathrm{~mm})$.

\subsection{Statistical analysis}

A Principal Component Analysis (PCA) was performed to summarize the physical, chemical and granulometric texture variables to ordinate possible groupings between the different seasons, sites or microhabitats of sampling. Using the scores of the PCA axes, a non-parametric analysis of variance (Kruskal-Wallis) was carried out to test the significance of the results, since the assumptions of homoscedasticity of variances had not been achieved.

The PCA axes were retained for interpretation according to Broken-stick criterion (the eigenvalues generated by the PCA should be higher than those generated at random in the Broken-stick and higher than three) (Gauch Junior, 1986; Jongman et al., 
1995). In this study, only PC 1 was selected for interpretation, PC 2 was used only to construct the graph.

In order to describe the variations in the structure of Chironomidae larvae between the different sites, seasons and microhabitats, the following attributes were used: i) Density (Ind. $\mathrm{m}^{-2}$ ), as an abundance measure, calculated per square meter using the area of the Surber sampler $\left(0.04 \mathrm{~m}^{2}\right)$; ii) Shannon-Wiener diversity index (H'), described by the equation: $H^{\prime}=-\sum\left(n_{\mathrm{i}} / N\right) \cdot \log _{2}\left(n_{\mathrm{i}} / N\right)$, where $n_{\mathrm{i}}$ is the number of individuals of the species $i$ and $N$, the total number of individuals; iii) Evenness (E), obtained through the expression $H^{\prime} / H_{\max }$, where $H_{\text {max }}$ is the diversity under maximum uniformity (Magurran, 1999) and iv) Taxonomic richness $(S)$ - number of registered taxa. The differences between the values of these attributes for seasons, sites and microhabitats were tested by running a factorial ANOVA considering the significance of $\mathrm{p}<0.05$.

The interaction between the Chironomidae assemblages in the different microhabitats was verified through the Jaccard coefficient that indicates similarity between sites considering the species composition (McCune and Mefford, 2002).

The similarity in the abundance of the benthic invertebrate community in the streams was examined using a non-metric multidimensional scaling (NMDS) being one of the most robust ordination analyses to nonlinear situations (Clarke, 1993). The distances were calculated through the Bray-Curtis similarity index. For the number of dimensions generated we choice $\mathrm{k}=2$. The resolution distortion in two dimensions is expressed by the value of $S$ (stress). The closer to zero the stress is, the better the fit between the original distance of the objects and the arrangement obtained by the analysis (Legendre and Legendre, 1998).

Based on the density of Chironomidae larvae population, a Detrended Correspondence Analysis (DCA) was performed to reduce biotic data dimensionality and ordinate the microhabitats. The most significant taxa were correlated with the axes 1 and 2 of the DCA through the Pearson Correlation Analysis (McCune and Mefford, 2002).

For the accomplishment of the multivariate analyses PCA and DCA, data was previously logarithmized $(\log x+1)$ and transformed $(b=X i, j) p$, with $\mathrm{p}=0.5$, respectively, to minimize the effect of outliers.

The multivariate analyses (PCA and DCA), the NMDS, the Jaccard coefficient and the values of Shannon-Wiener diversity and evenness were carried out in the software PC-ORD version 5.0 (McCune and Mefford, 2002). The analysis of variance and Pearson correlation as well as the graphs were done using Statistica 7.1 (2005).

\section{Results}

\subsection{Physical and chemical characterization of the sampling sites}

No marked and statistically significant differences were detected ( $p=0.4)$ in the values of physical and chemical water variables, between the different streams and their respective sampling sites and seasons (Table 1).

Both PC 1 and PC2 added up to $47.6 \%$ of explanation of variability of environmental data analyzed (Table 1). However, no grouping pattern statistically significant was identified for the streams, sites or seasons through the PCA (Figure 2a).

The scores 1 and 2 of the principal components did not provide differentiated groups, indicating that the environmental variables did not follow trends or patterns for the streams, sites and seasons. The PC 1 of PCA was negatively influenced by the percentage of coarser sand and higher flow, though positively by the percentage of medium, fine and very fine sand (Figure $2 b$ ).

The granulometric texture in the different sites and streams was statistically similar, with substrate predominantly composed of pebbles, granules and very coarse sand. In these environments, in general, the coarse organic matter occurred at higher percentage than the fine organic matter (Figure 2a, b).

\subsection{Chironomidae Assemblage}

A total of 6,469 Chironomidae larvae were collected, totaling 96 taxa belonging to the subfamilies Chironominae (44 taxa), Tanypodinae (23 taxa) and Ortocladiinae (19 taxa). While analyzing the density, richness, evenness and diversity (Shannon-Wiener diversity index $\left(\mathrm{H}^{\prime}\right)$ ) of assemblage in relation to season, site and microhabitat, significant differences were recorded

Table 1. Eigenvalues of the Principal Component Analysis by the Broken-stick criterion, percentage of explanation of the axes, and Kruskal-Wallis analysis of variance (KW). P: significance.

\begin{tabular}{cccccc}
\hline Axis & Eingenvalues & \% of Variance & \% Acumulation & Broken-stick & KW-H (11,12) \\
\hline 1 & 5.54 & 32.588 & 32.588 & 3.44 & $\mathrm{p}=0.4$ \\
2 & 2.555 & 15.029 & 47.617 & 2.44 & $\mathrm{p}=0.4$ \\
\hline
\end{tabular}


PCA

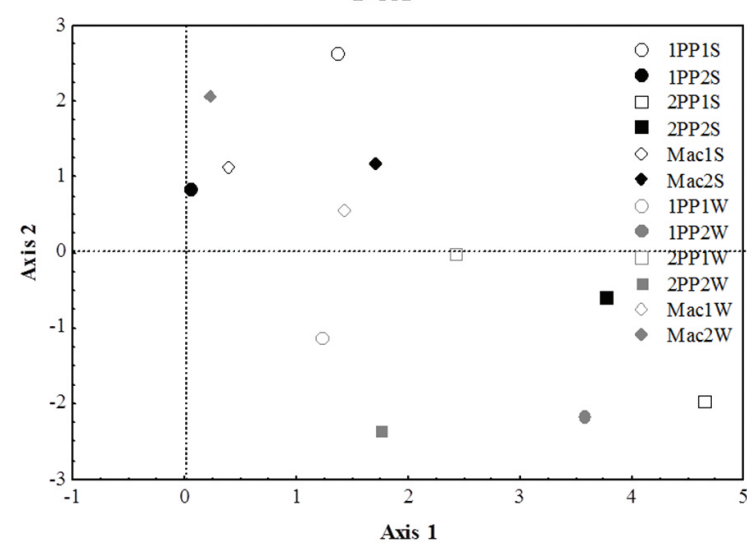

(a)

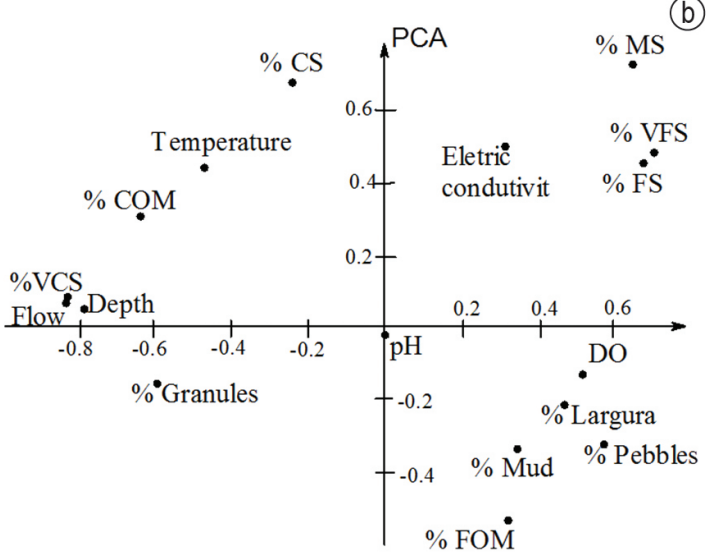

Figure 2. Scores ordination of the PC 1 and 2 of PCA for the sampled streams (a) and the vectors of the variables physical, chemical and of grain texture with the score of the PC 1 and 2 of PCA (b). 1PP1S: stream 1 of Poço Preto site 1, Summer; 1PP2S: stream 1 of Poço Preto site 2, Summer; 2PP1S: stream 2 of Poço Preto site 1, Summer; 2PP2S: stream 2 of Poço Preto site 2, Summer; Mac1S: stream of Macuco site 1, Summer; Mac2S: stream of Macuco site 2, Summer; 1PP1W: stream 1 of Poço Preto site 1, Winter; 1PP2W: stream 1 of Poço Preto site 2, Winter; site 2; 2PP1W: stream 2 of Poço Preto site 1, Winter; 2PP2W: stream 2 of Poço Preto site 2, Winter; Mac1W: stream of Macuco site 1, Winter; Mac2 W: stream of Macuco site 2, Winter; VFS = very fine sand; FS = fine sand; MS = medium sand; $\mathrm{CS}=$ coarse sand; VCS = very coarse sand, COM: coarse organic matter, FOM: fine organic matter.

in larval distribution for the four observed microhabitats (Figures 3a to 3i).

Among the microhabitats, higher density, richness and diversity of Chironomidae larvae occurred in the deposits of litter, both in the riffle (RL) and pool (PL). The highest evenness was observed for the taxa collected in the substrate of the pool (PS) and riffle (RS).

In the latter, lower values of richness and diversity were recorded (Figure 3g, h, i).

Despite that densities and richness observed in different sampling sites had not presented significant differences, increase in these biological attributes in site 2 in relation to site 1 , especially in the stream 2 of Poço Preto and Macuco was notable (Figure 3a, b, c).

\subsection{Microhabitats}

With regard to microhabitats, the highest richness was observed in the deposit of litter in pool and riffle, with $81 \%$ and $72 \%$ of the total registered taxa, respectively. In the substrate of pool and riffle, $65 \%$ and $49 \%$, respectively, of the total Chironomidae richness was recorded (Table 2). For richness, mean densities were higher in the litter pool and riffle. In the areas with riffle, LR and SR, the greatest density was of Rheotanytarsus, whereas Caladomyia sp. 5 was abundant in the litter pool, and Polypedilum (Tripodura), in the substrate pool (Table 2).
Of the total of 96 taxa registered, 33 were commonly found in the four microhabitats, distributed among eleven genera of the subfamilies Chironominae (Caladomyia, Lauterborniella, Oukuriella, Polypedilum, Pseudochironominae, Rheotanytarusus, Stempellinella, Stenochironomus, Tanitarsinii, Tanytarsus and Zavreliella), six representatives of the subfamily Ortocladiinae (Corynoneura, Cricotopus, Lopescladius, Nanocladius, Onconeura and Parametriocnemus) and four belonging to the subfamily Tanypodinae (Ablabesmyia (Karelia), Hudsonimyia, Larsia and Djamabatista).

A high overlap was also registered among the litter pool (PL) microhabitats, litter riffle (RL) and substrate pool (PS) with 15 morphospecies represented by Cardiocladius sp., Clinotanypus sp., Criptochironomus sp.2, Denopelopia sp., Endotribelos sp.1, sp.3 and sp.4, Labrundinia sp.1, Polypedilum sp.2, Parapentaneura sp.1, Pentaneura sp., Stempellina sp., Tanypodinae sp., Xestochironomus sp. and Zavreliella sp1.

The grouping analysis of Jaccard also indicated high similarity between microhabitats PL, RL and PS, differing from the substrate riffle (RS). Among them, the highest number of exclusive species was within the litter pool microhabitat (12) followed by the substrate pool (6), litter riffle (4) and substrate riffle with only one species (Figures 4a, b). 

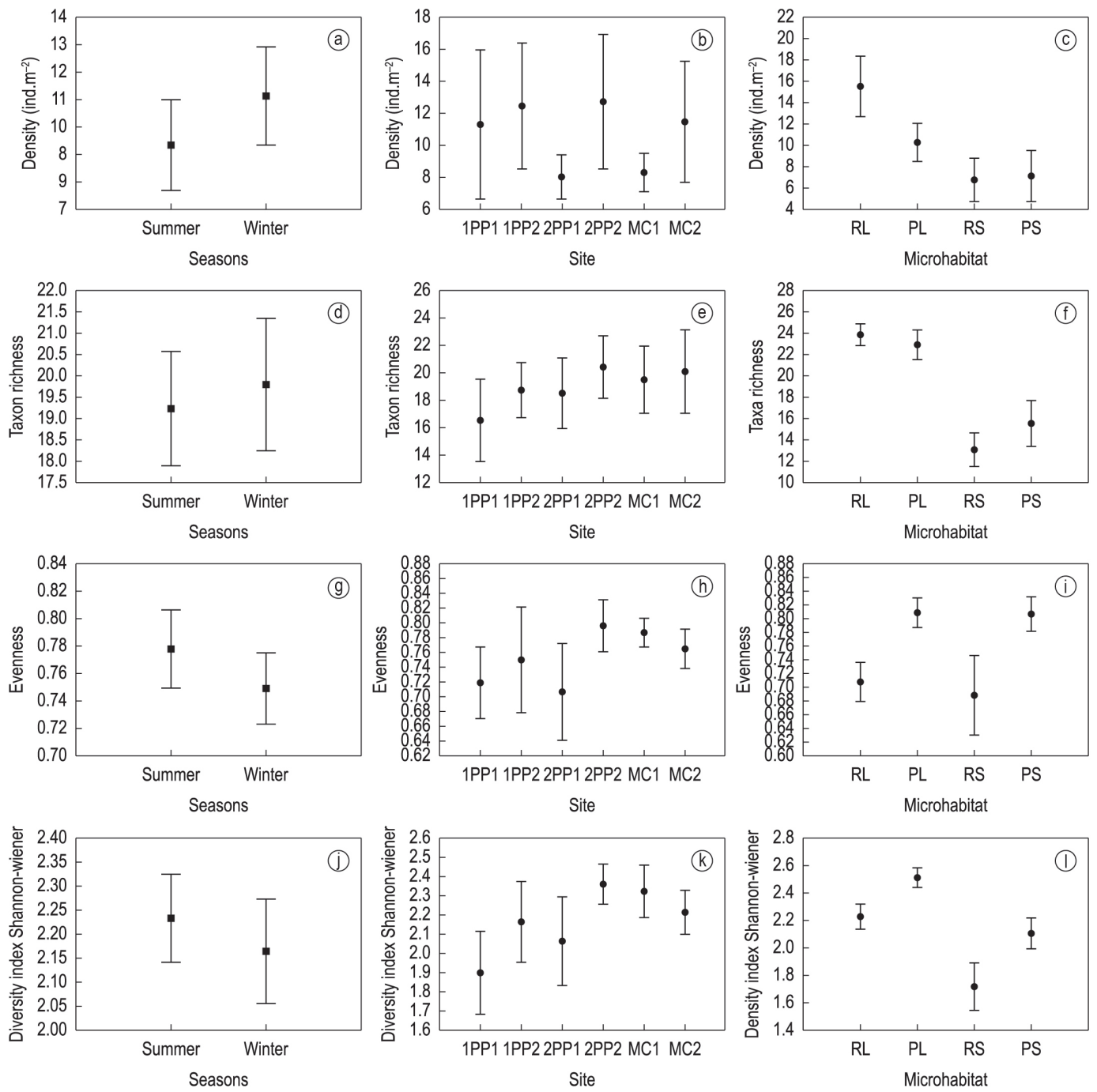

Figure 3. Mean density (a, b, c), richness (d, e, f), evenness (g, h, i) and diversity (j, k, l) of Chironomidae assemblage per seasons, sites and microhabitats. 1PP1: stream 1 of Poço Preto site 1, 1PP2: stream 1 of Poço Preto site 2, 2PP1: stream 2 of Poço Preto site 1, 2PP2: stream 2 of Poço Preto site 2, MC1: stream Macuco site 1, MC2: stream Macuco site 2. FC: riffle litter, FR: pool litter; SC: riffle sediment, SR: pool sediment.

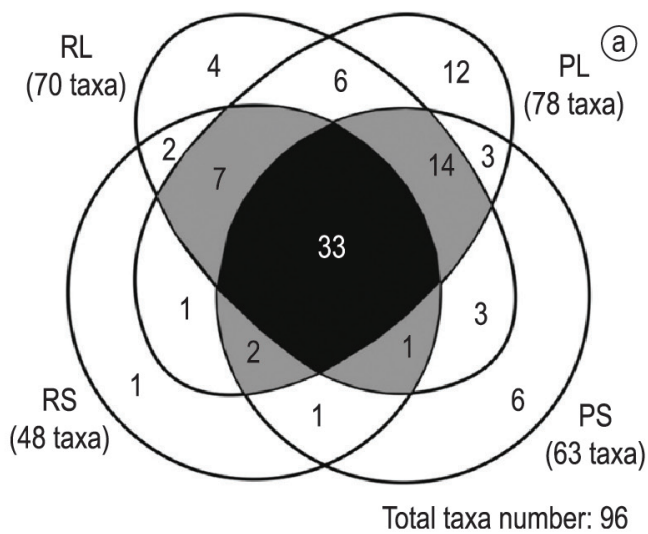

(b)

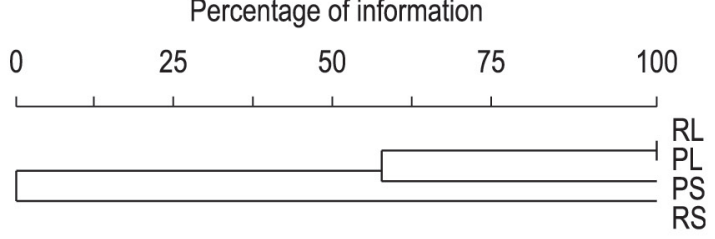

Figure 4. Schematic diagram of the distribution (a) and Grouping analysis by Jaccard Coefficient (b) of the Chironomidae taxa per microhabitats sampled. RL: riffle litter, PL: pool litter, RS: riffle sediment, PS: pool sediment. 


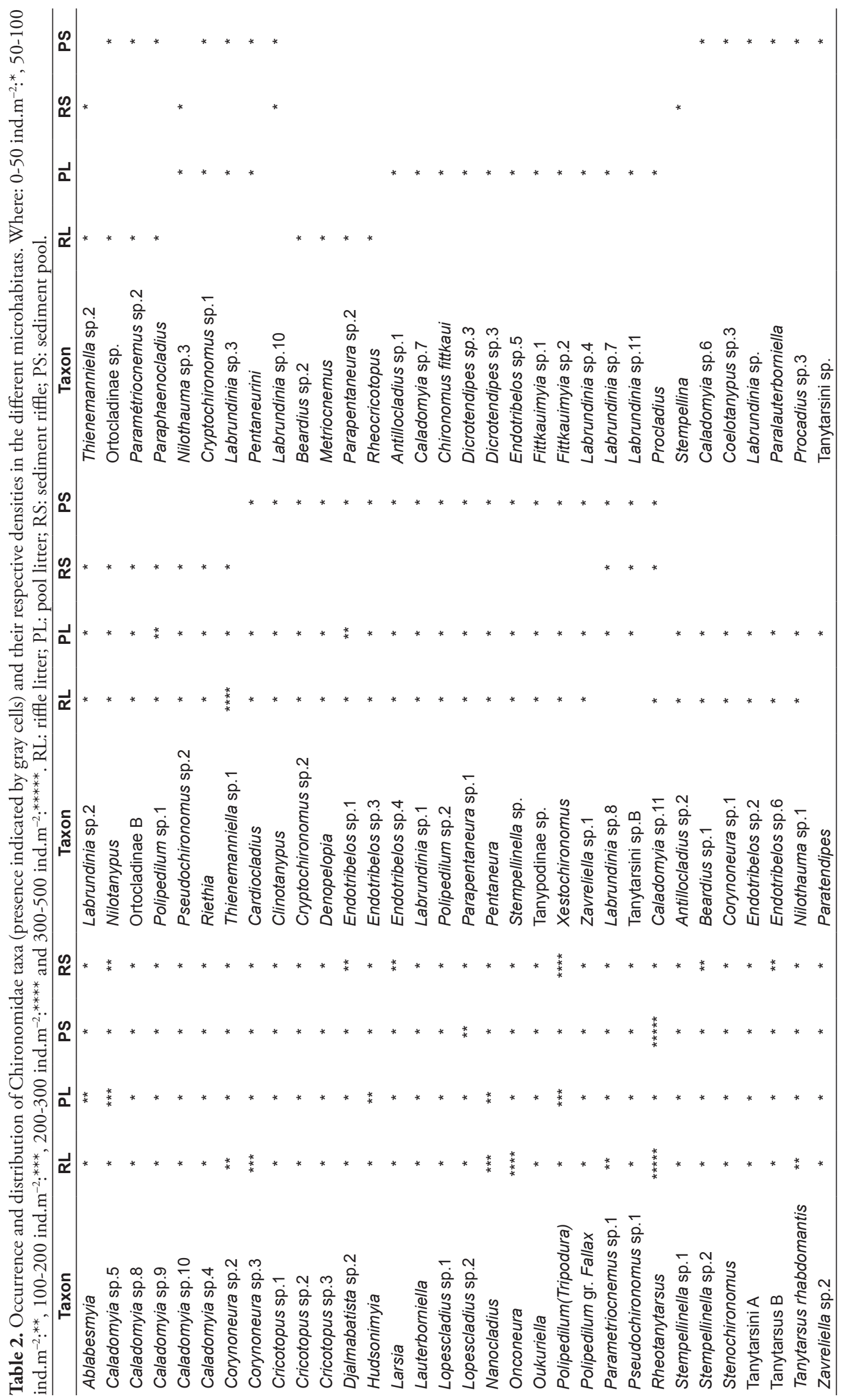


The NMDS evidenced a value of stress around 0.04 and $\mathrm{p}=0.04$ (Monte Carlo Test), ensuring a good reliability in interpreting the abundance results. This analysis pointed out a greater similarity among the microhabitats of riffle (evidenced can be found in Figure 5) considering the overlap of the closed points. The litter pools were more similar to each other (points more grouped) than the substrate rapids (points more disperse). On the other hand, the microhabitats of pool were less similar to each

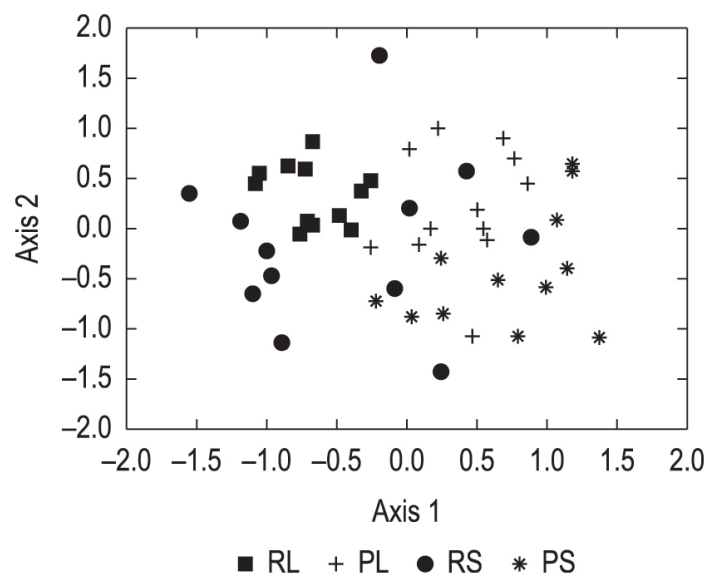

Figure 5. Non-metric multidimensional scaling (NMDS) for the density of benthic invertebrates in the microhabitats of the streams of the Iguaçu National Park. RL: riffle litter, PL: pool litter, RS: riffle sediment, PS: pool sediment. other, and in relation to the riffle (more spread points) (Figure 5).

The results of the DCA, based on the densities of taxa registered for the different microhabitats, presented eigenvalues of 0.26 for the axis 1 and 0.15 for axis 2 . The scores distribution indicated a trend in the distribution of the different taxa, in relation to the microhabitats of riffle and pool, regardless to substrate or presence of litter (Figure 6a).

The Pearson correlation performed between the scores of the DCA axes and the analyzed taxa indicated that Caladomyia sp.5, Stempellinella sp.2, Polypedilum (Tripodura) and Djalmabatista sp.2 have presented a highly positive correlation for axis 1 , while for axis 2, correlation was observed for Lopescladius sp.2. Negatively, axis 1 had strong correlation with Rheotanytarsus, Onconeura and Parametriocnemus sp.2, and axis 2, with Fittkauimyia sp.1 (Figure 6b).

\section{Discussion}

The results pointed out physical, chemical granulometric texture similarities of all three streams. In the same way, there were no significant differences within biological attributes (richness, Shannon diversity index, evenness and density) in relation to season and different sampling sites, indicating that environmental variables exerted no influence on the composition of different Chironomidae taxa.
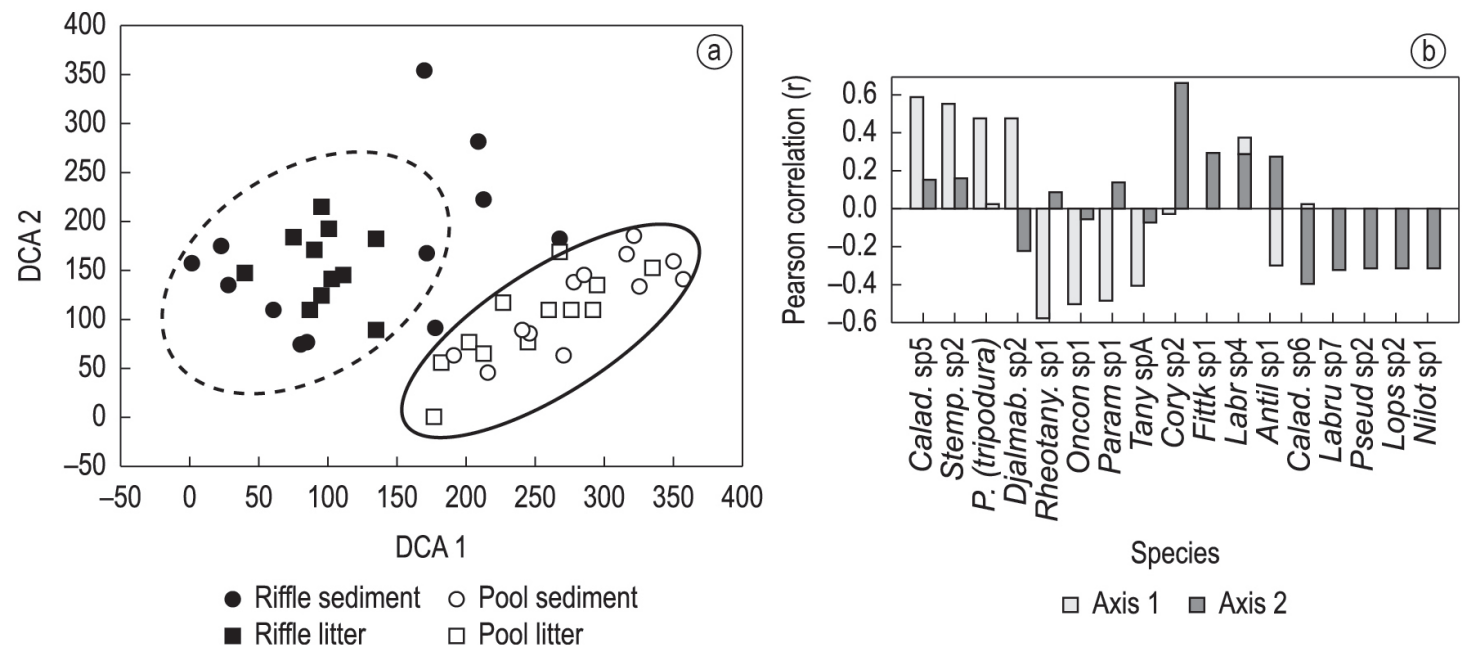

Species

$\square$ Axis $1 \quad \square$ Axis 2

Figure 6. Scores ordination of the axes 1 and 2 of DCA per microhabitats sampled (a) and Pearson correlation between the most significant taxa with the scores of the axes 1 and 2 of DCA (b). Calad. Sp5: Caladomyia sp.5; Stemp.sp2: Stempellinela sp.2; P.(Tripodura): Polypedilum (Tripodura); Djalmab sp2: Djalmabatista sp.2; Rheotany. sp1: Rheotanytarsus sp1; Oncon sp1: Onconeura; Param sp1: Parametriocnemus sp.1: Tany spA: Tanytarsini sp.A; Cory sp2: Corynoneura sp.2; Fittk sp1: Fittkanimyia sp.1; Labr sp4: Labrundinia sp.4; Antil sp1: Antillocladius sp.1; Calad. sp6: Caladomyia sp.6; Labrun sp7: Labrundinia sp.7; Pseud sp2: Pseudochironomus sp.2; Lops sp2: Lopescladius sp.2; Nilot sp1: Nilotanypus sp.1. 
However, these same biological attributes were significantly different when compared to the four microhabitats. Thus, among the different variables, the heterogeneity of environments was crucial to the occurrence of different colonization patterns of the assembly of chironomids, as initially supposed in our hypothesis.

The high environmental integrity and low-order streams may have contributed to the increased heterogeneity of microhabitats and therefore favored the high richness and diversity of larvae of this family. Since the large contribution of allochthonous material source from riparian vegetation is favorable to colonization of aquatic invertebrates (Allan and Castillo, 2007; Callisto et al., 2007; Moretti et al., 2007; Sanseverino and Nessimian, 2008; Rosin et al., 2010). However, this fact is also a controversy topic, because some studies have demonstrated that the richness tend to be lower in headwater streams and increase with the stream order (Clarke et al., 2008), although the contribution of these smaller streams for the local richness (Grönroos and Heino, 2012) and regional diversity becomes apparent only at larger scales (Clarke et al., 2008). Nevertheless, the high taxa richness in our study, considering only 3 streams and two sampling periods, demonstrates the importance of these preserved environments for the maintenance of the group, especially when compared to the Chironomidae richness from other regions worldwide (Ferrington-Junior, 2008).

A lot of studies have emphasize the positive relationship and importance between the presence and quality of riparian vegetation both to Chironomidae and other invertebrates (Callisto et al., 2002; Kleine and Trivinho-Strixino, 2005; Callisto et al., 2007; Hepp et al., 2008; Ligeiro et al., 2013; Bruder et al., 2014). The vegetal cover also provides greater stability in terms of flow and consequently of community structure (Suriano and Fonseca-Gessner, 2004) that contribute to the habitat heterogeneity ensuring an assemblage with high richness, composed of genera and species with diversified ecological requirements and widely distributed (Amorim et al., 2004; Brown, 2007; Kon and Korukura, 2011), as found in the present study.

The high richness and diversity is related to the high number of taxa uncommon in other types of environments such as Hudsonimyia, Parametriocnemus, Cardiocladius, Antillocladius, Orthocladiinaesp., Paraphaenocladius, Metriocnemus, Fittkanimyia; or specialist taxa as Stenochironomus e Xestochironomus, commonly associated with woody substrates and Oukuriella, genus inhabiting freshwater sponges (Trivinho-Strixino, 2011). The higher richness and uncommon taxa can be due to the environmental conservation of the sites that favors the maintenance of the microhabitats heterogeneity and consequently promotes better conditions of colonization to the Chironomidae assemblage (Suriano and Fonseca-Gessner, 2004; Siqueira and Trivinho-Strixino, 2005).

The number of rare species is a direct function of the richness: the more species an assemblage, the more species are classified as rare. This statement explains the fact that a higher number of rare species was found in the richest substrate (PL), and a lower number of rare species in substrates of lower richness (RS). Furthermore, although the definitions of rarity are necessarily arbitrary, there is a consensus that a species may be rare or common in relation to its number or distribution, and, despite some exceptions, the most widely distributed species tend to occur in higher abundance (Gaston, 1994).

Within microhabitats, Chironomidae larvae with varied ecological requirements were found as well despite the fact that specialized taxa usually is restricted to a single type of substrate, (such as Stempellinella and Tanytarsini, being characteristical for sandy bottom, or, Beardius and Zavreliella associated with vegetal fragments), to those genera commonly found in different lotic ecosystems, such as Larsia, Ablabesmyia (Karelia), Cricotopus, Onconeura and Parametriochinemus (TrivinhoStrixino, 2011).

The initial hypothesis of this study that in microhabitat rapid litter (RL), attributes of the communities would be higher was not supported. We expected that in fast waters, the specimens would use the habitat conditions to displacement and getting food, and that the presence of plant fragments arrested the currents would provide stability, and consequently conditions to harbor a greater variety of taxa with diverse ecological needs (Coffman and Ferrington-Junior, 1984) however, most taxa preferred habitats compounded of litter in pool areas (PL).

Since the slower water speed facilitates the colonization and permanence of the specimens, and increased the feed supply by the accumulation of organic detritus, as wood, leaves, particulate material and even periphyton present in higher amount (Coffman and Ferrington-Junior, 1984; Callisto et al., 2007; König and Santos, 2013). In this microhabitat we can highlight Stenochironomus, Endotribelos and Cryptochrironomus, can be 
highlighted being exclusively xylophages (miner wood) and therefore reflecting the high availability of food from riparian vegetation (Siqueira and Trivinho-Strixino, 2005). Besides being a source of food, pool areas also provided shelter and is used to build tubes by tubificid larvae such as Lauterboniella, Corinoneura, and Nanocladius as observed in the literature (Hirabayashi and Wotton, 1999; Sanseverino and Nessimian, 2008).

In this way, pool litter (PL) microhabitat includes features like the availability of organic matter coupled to stability derived from the slow flow, thereby favoring colonization and permanence of a wide variety of taxa. This contributed to a higher richness and density of Chironomidae larvae as well. Within pool microhabitats, the highest number of unique morphotypes as Antillocladius, Caladomyia, Fitkauimyia, Procladius and Dicrotendipes species, know to demand higher environmental requirements, were found (Larnon and Carter, 2000). The dominant genus was Caladomyia, commonly associated with shallow sediments and Polypedilum (Tripodura) frequently found in different lotic and lentic environments (TrivinhoStrixino, 2011; Sanseverino and Nessimian, 2008).

On the other hand, in pool substrates (PS) without deposit of organic matter, restricting the availability of food, we noticed a large reduction in number of biological attributes, probably caused by the low availability and variety of food.

However, lower density, diversity and richness were recorded in rapid substrate (RS) environments characterized by greater instability. This indicates that in the absence of particles to attach, the larvae are exposed to the strength of the current, causing that in the habitats of fast water the colonization is realized by species having specific adaptations for fixation such as two dominant species at this site: Rheotanytarsus, (larvae constructors of tubes) that feed on particles brought by the current (HenriquesOliveira et al., 2003) and Lopescladius, also a tube constructor, commonly found in sand substrates streams (Sanseverino and Nessimian, 2001). These environmental requirements may explain why the taxa grouped in this microhabitat are of such difference when compared to those occurred in the other groups.

Moreover, in both pool microhabitats (PL, PS) a higher evenness was found, indicating that in these sites the taxonomic abundance was similar, including the high density of Polypedilum (Tripodura) and Caladomyia sp. 5 larvae. According to Roque et al. (2000) and Fonseca-Leal et al. (2004)
Caladomyia (Tanytarsini Tribe), are predominant in natural areas and related with environmental conditions characteristic of less impacted areas. On the other hand, Polypedilum (Tripodura) represents one of the most diverse and widespread species group (Trivinho-Strixino, 2011).

Nevertheless, the composition and structure of Chironomidae assemblage were directly related to the availability and type of substrate of streams. These results emphasize the importance of habitat heterogeneity and of flow dynamics for benthic communities (Sanseverino et al., 1998; HenriquesOliveira et al., 2003).

Furthermore the microhabitats of higher preference for Chironomidae assembly were pool litters followed by riffle litters, highlighting how the deposits and fragments of leaves in streams are essential to ensure colonization in greater diversity, especially in relation to microenvironments exposed to current.

Our understanding of the conservation status of both species and ecosystem is poor worldwide (MacNally and Fleishman, 2004). However, streams in fully preserved areas to assess the distribution of biological communities are increasingly scarce (Tupinambás et al., 2007). Thus, assess their current state and estimating how environmental characteristics may affect their future condition are vital measures for making decisions that maximize protection of biodiversity and the services provided by the ecosystem. As demonstrated, environmental heterogeneity can be linked to how rich an environment will be in number of taxa of Chironomidae, thus contributing to future studies on composition and richness of this community. Ensuring habitats heterogeneity is essential to maintaining the diversity of Chironomidae, considering that the areas of greatest preference for colonization of the assembly are in locations of materials deposition.

Therefore, environmental preservation areas contribute decisively to the integrity of aquatic ecosystems, reflected by the community attributes, besides the high ecological diversity favored by the maintenance of structural patterns and habitat heterogeneity. Despite their importance, few studies had been performed with ecological and taxonomical focus on aquatic invertebrates in conservation units.

\section{Acknowledgements}

The authors wish to express their gratitude to Maximilian Berger from Universität Hohenheim in German for the English revision. To the Parque 
Nacional do Iguaçu/ICMBio for the financial and logistic support, to the Strictu Sensu PostGraduation Program in Fisheries Resources and Fishing Engineering of the State University of West of Paraná and to the Laboratory of Zoobenthos of the State University of Maringá.

\section{References}

ALLAN, JD. and CASTILLO, MM. 2007. An introduction to fluvial ecosystems. In Allan, JD. and Castillo, MM. Stream ecology: structure and function of running waters. Dordrecht: Springer. p. 1-12.

AMORIM, RM., HENRIQUE-OLIVEIRA, AC. and NESSIMIAN, J. 2004. Distribuição espacial e temporal das larvas de Chironomidae (Insecta: Diptera) na seção ritral do rio Cascatinha, Nova Friburgo, Rio de Janeiro, Brasil. Lundiana, vol. 5, no. 2, p. 119-127.

BERG, HB. 1995. Larval food and feeding behavior. In ARMITAGE, PD., CRANSTON, PS. and PINDER, LCV. The chironomidae: the biology and ecology of non-biting midges. London: Chapman \& Hall. p. $136-168$.

BIASI, C., TONIN, AM., RESTELLO, RM. and HEPP, LU. 2013. The colonization of leaf litter by Chironomidae (Diptera): the influence of chemical quality and exposure duration in a subtropical stream. Limnologica-Ecology and Management of Inland Waters, vol. 43, no. 6, p. 427-433. http://dx.doi. org/10.1016/j.limno.2013.01.006

BROWN, BL. 2007. Habitat heterogeneity and disturbance influence patterns of community temporal variability in a small temperate stream. Hydrobiologia, vol. 586, p. 93-106. http://dx.doi. org/10.1007/s10750-006-0531-3

BRUDER, A., SCHINDLER, MH., MORETTI, MS. and GESSNER, MO. 2014. Litter decomposition in a temperate and a tropical stream: the effects of species mixing, litter quality and shredders. Freshwater Biology, vol. 59, no. 3, p. 438-449. http:// dx.doi.org/10.1111/fwb.12276

CALLISTO, M., BARBOSA, FAR. and MORENO, P. 2002. The influence of eucalyptus plantations on the macrofauna associated with Salvinia auriculata in southeast Brazil. Brazilian Journal of Biology, vol. 62, no. 1, p. 63-68. PMid:12185924. http://dx.doi. org/10.1590/S1519-69842002000100008

CALLISTO, M., GONÇALVES JUNIOR, JF. and GRAÇA, AS. 2007. Leaf litter as a possible food source for chironomids (Diptera) in Brazilian and Portuguese headwarter streams. Revista Brasileira de Zoologia, vol. 24, no. 2, p. 442-448. http://dx.doi. org/10.1590/S0101-81752007000200023

CLARKE, A., MACNALLY, R., BOND, N. and LAKE, PS. 2008. Macroinvertebrate diversity in headwater streams: a review. Freshwater Biology, vol. 53, no. 9, p. 1707-1721. http://dx.doi.org/10.1111/j.13652427.2008.02041.x

CLARKE, KR. 1993. Non-parametric multivariate analyses of changes in community structure. Australian Journal of Ecology, vol. 18, p. 117-143. http://dx.doi.org/10.1111/j.1442-9993.1993. tb00438.x

COFFMAN, WP. and FERRINGTON-JUNIOR, LC. 1984. Chironomidae. In MERRITT, RW. and CUMMINS, KW. An introduction to the aquatic insects of North America. 2nd ed. Dubuque: Kendall/ Hunt Pub. Co. p. 551-554.

CRANSTON, PS. 1995. Introduction. In ARMITAGE, PD., CRANSTON PS. and PINDER LCV., eds. The chironomidae: the biology and ecology of non-biting midges. London: Chapman \& Hall, London. p. 1-8.

DEVINE, JA. and VANNI, MJ. 2002. Spatial and seasonal variation in nutrient excretion by benthic invertebrates in a eutrophic reservoir. Freshwater Biology, vol. 47, no. 1, p. 1107-1121.

EPLER, JH. 2001. Identification manual for the larval Chironomidae (Diptera) of North and South Carolina: a guide to the taxonomy of the midges of the Southeastern United States, including Florida. Palatka: Department of Environmental and Natural Resources, Division of Water Quality, Raleigh and St. Johns River Water Management District. 526 p. (Special Publication SJ2001-SP13). Available from: <http://www.esb.enr.state.nc.us/BAUwww/ Chironomid.htm>. Access in: 07 set. 2010.

FERRINGTON-JUNIOR, LC. 1984. Drift dynamics of Chironomidae larvae: preliminary results and discussion of important of mesh size and level of taxonomic identification in resolving Chironomidae diel drift patters. Hydrobiologia, vol. 114, no. 3, p. 215-227. http://dx.doi.org/10.1007/BF00031873

FERRINGTON-JUNIOR, LC. 2008. Global diversity of non-biting midges (Chironomidae; Insecta-Diptera) in freshwater. Hydrobiologia, vol. 595, p. 447-455. http://dx.doi.org/10.1007/s10750-007-9130-1

FONSECA-LEAL, JJ., ESTEVES, FA. and CALLISTO, M. 2004. Distribution of Chironomidae larvae in an Amazonian floodplain lake impacted by bauxite tailings (Brazil). Amazoniana, v. 18, no. 1/2, p. 109123.

GASTON, KJ. 1994. Rarity. London: Chapman and Hall. 395 p.

GAUCH JUNIOR, HG. 1986. Multivariate analysis in community ecology. Cambridge: Cambridge University Press. 298 p.

GRAÇA, MAS. 2001. The role of invertebrates on leaf litter decomposition in streams: a review. International Review of Hydrobiology, vol. 86, no. 4-5, p. 383-394. http://dx.doi. org/10.1002/1522-2632(200107)86:4/5<383::AIDIROH383>3.0.CO;2-D 
GRÖNROOS, M. and HEINO, J. 2012. Species richness at the guild level: effects of species pool and local environmental conditions on stream macroinvertebrate communities. Journal of Animal Ecology, vol. 81, no. 3, p. 679-691. PMid:22220712. http://dx.doi.org/10.1111/j.13652656.2011.01938.x

HENRIQUES-OLIVEIRA, AL., DORIVILLÉ, LFM. and NESSIMIAN, JL. 2003. Distribution of Chironomidae larvae fauna (Insecta: Diptera) on different substrates in stream at Floresta da Tijuca, RJ, Brazil. Acta Limnologia Brasiliensia, vol. 15, no. 2, p. 69-84.

HEPP, LU., BIASI, C., MILESI, SV., VEIGA, FO. and RESTELLO, RM. 2008. Chironomidae (Diptera) larvae associated to Eucalyptus globulus and Eugenia uniflora leaf litter in a subtropical stream (Rio Grande do Sul, Brazil). Acta Limnologica Brasiliesia, vol. 20, no. 4, p. 345-350.

HIRABAYASHI, K. and WOTTON, RS. 1999. Organic matter processing by chironomid larvae (Diptera:Chironomidae). Hydrobiologia, vol. 382, p. 151-159. http://dx.doi. org/10.1023/A:1003472329603

INOUE, E., KAWAI, K. and IMABAYASHI, H. 2005. Species composition and assemblage structure of chironomid larvae (Diptera: Chironomidae) attaching to the artificial substrates in a Japanese temperate basin, in relation to the longitudinal gradient. Hydrobiologia, vol. 543, p. 119-133. http:// dx.doi.org/10.1007/s10750-004-6950-0

JONGMAN, RHG., TER BRAAK, CJF. and VAN TONGEREN, OFR. 1995. Data analysis in community and landscape ecology. Cambridge: Cambridge University Press. 292 p.

KLEINE, P. and TRIVINHO-STRIXINO, S. 2005. Chironomidae and other aquatic macroinvertebrates of a first order stream: community response after habitat fragmentation. Acta Limnologica Brasiliensia, vol. 17, no. 1, p. 81-90.

KON, K. and KUROKURA, H. 2011. Influence of a microhabitat on the structuring of the benthic macrofauna community in a mangrove forest. Hydrobiologia, vol. 617, no. 1, p. 205-216. http:// dx.doi.org/10.1007/s10750-011-0718-0

KÖNIG, R. and SANTOS, S. 2013. Chironomidae (Insecta: Diptera) of different habitats and microhabitats of the Vacacaí-Mirim River microbasin, Southern Brazil. Anais da Academia Brasileira de Ciências, vol. 85, no. 3, p. 975-985. PMid:24068087. http://dx.doi.org/10.1590/S000137652013000300010

LARNON, LMC. and CARTER, CE. 2000. Chironomidae in Lough Neagh, Northern Ireland. Verhandlungen des Internationalen Verein. Limnologie, vol. 27, p. 2383-2387.
LEGENDRE, P. and LEGENDRE, P. 1998. Numerical ecology. 2nd ed. ing. Amsterdam: Elsevier Scientific Pub. Co.. 970 p. (Developments in Environmental Modelling, 20).

LIGEIRO, R., HUGHES, RM., KAUFMANN, PR., MACEDO, DR., FIRMIANO, KR., FERREIRA, WR., OLIVEIRA, D., MELO, AS. and CALLISTO, M. 2013. Defining quantitative stream disturbance gradients and the additive role of habitat variation to explain macroinvertebrate taxa richness. Ecological indicators, vol. 25, p. 45-57. http://dx.doi. org/10.1016/j.ecolind.2012.09.004

MACNALLY, R. and FLEISHMAN, E. 2004. A successful predictive model of species richness based on indicator species. Conservation Biology, vol. 18, no. 3, p. 646-654. http://dx.doi.org/10.1111/j.15231739.2004.00328_18_3.x

MAGURRAN, AE. 1999. Ecological diversity and his measurement. New Jersey: Princeton University Press. $300 \mathrm{p}$.

MCCUNE, B and MEFFORD, MJ. 2002. PC-ORD: multivariate analysis of ecological data, version 4 . Gleneden Beach: MjM Software Design. 300 p.

MORETTI, MS., GONÇALVES JÚNIOR, JF., LIGEIRO, R. and CALLISTO, M. 2007. Invertebrates colonization on native tree leaves in a neotropical stream (Brazil). International Review of Hydrobiology, vol. 92, no. 2, p. 199-210. http:// dx.doi.org/10.1002/iroh.200510957

PINDER, LCV. 1986. Biology of freshwater Chironomidae. Annual Review of Entomology, vol. 31, p. 1-23. http://dx.doi.org/10.1146/annurev. en.31.010186.000245

PINHA, GD., AVIZ, D., LOPES FILHO, DR., PETSCH, DK., MARCHESE, MR. and TAKEDA, AM. 2013. Longitudinal distribution of Chironomidae (Diptera) downstream from a dam in a Neotropical river. Brazilian Journal of Biology, vol. 73, no. 3, p. 549-558. PMid:24212696. http:// dx.doi.org/10.1590/S1519-69842013000300013

RAE, JG. 2004. The colonization response of lotic chironomid larvae to substrate size and heterogeneity. Hydrobiologia, vol. 524, p. 115-124. http://dx.doi. org/10.1023/B:HYDR.0000036126.50550.13

RAIO, CB., ESPINOZA, AV. and BENNEMANN, ST. 2011. Similarity and diversity between aquatic insect populations in streams of first and second order, south of Brazil. Semina: Ciências Biológicas e da Saúde, v. 32, no. 1, p. 69-76.

ROQUE, FO., CORBI, JJ. and TRIVINHOSTRIXINO, S. 2000. Consideraçóes sobre a utilizaçâo de larvas de Chironomidae (Diptera) na avaliação da qualidade da água de córregos do Estado de São Paulo. In ESPÍNDOLA, ELG., PASCHOAL, CMRB., ROCHA, O., BOHRER, MBC. and OLIVEIRA NETO, AL., eds. Ecotoxicologia: 
perspectivas para o século XXI. São Carlos: Rima Artes e Textos. p. 115-126.

ROSIN, GC., OLIVEIRA-MANGAROTTI, DP. and TAKEDA, A. 2010. Chironomidae (Diptera) community structure in two subsystems with different states of conservation in a floodplain of Southern Brazil. Acta Limnologica Brasiliensia, v. 22, no. 3, p. 276-286. http://dx.doi.org/10.4322/ actalb.02203004

RYLANDS, AB. and BRADOW, K. 2005. Brazilian protected areas. Conservation Biology, vol. 19, no. 3, p. 612-618. http://dx.doi.org/10.1111/j.15231739.2005.00711.x

SANSEVERINO, AM. and NESSIMIAN, JL. 2001. Hábitats de larvas de Chironomidae (Insecta Diptera) em riachos de Mata Atlântica no Estado do Rio de Janeiro. Acta Limnologica Brasiliensia, vol. 13, no. 1, p. 29-38.

SANSEVERINO, AM. and NESSIMIAN, JL. 2008. Larvas de Chironomidae (Diptera) em depósito de folhiços submerso em um riacho de primeira ordem da Mata Atlântica (Rio de Janeiro, Brasil). Revista Brasileira de Entomologia, vol. 52, no. 1, p. 95-104. http://dx.doi.org/10.1590/S008556262008000100017

SANSEVERINO, AM., NESSIMIAN, JL. and OLIVEIRA, ALH. 1998. A fauna de Chironomidae (Diptera) em diferentes biótopos aquáticos na Serra do Subaio (Teresópolis, RJ). Séries Oecologia Brasiliensis, vol. 5, p. 253-263. http://dx.doi. org/10.4257/oeco.1998.0501.18

SILVEIRA, LS., MARTINS, RT., SILVEIRA, GA., GRAZUL, RM., LOBO, DP. and ALVES, RG. 2013. Colonization by Chironomidae larvae in decomposition leaves of Eichhornia azurea in a lentic system in southeastern Brazil. Journal of Insect Science, vol. 13, no. 20, p.1-13. Available from: <http://www. insectscience.org/13.20>. Access in: 29 jun 2014.
SIQUEIRA, T. and TRIVINHO-STRIXINO, S. 2005. Diversidade de Chironomidae (Diptera) em dois córregos de baixa ordem na região central do Estado de São Paulo, através da coleta de exúvias de pupa. Revista Brasileira de Entomologia, vol. 49, no. 4, p. 531-534. http://dx.doi.org/10.1590/S008556262005000400013

StatSoft. 2005. Statistica: data analysis software system. Version 7.1. Tulsa.

SUGUIO, K. 1973. Introdução à sedimentologia. São Paulo: Edgard Blücher. 317 p.

SURIANO, MT. and FONSECA-GESSNER, AA. 2004. Chironomidae (Diptera) larvae in stream of Parque Estadual de Campos do Jordão, São Paulo State, Brasil. Acta limnologica Brasiliensia, vol. 16, no. 2, p. 126-136.

TRIVINHO-STRIXINO, S. 2011. Larvas de Chironomidae: guia de identificação. São Carlos: UFSCar. 371 p.

TRIVINHO-STRIXINO, S. and STRIXINO, G. 1995. Larvas de Chironomidae (Diptera) do Estado de São Paulo: guia de identificaçáo e diagnose dos gêneros. São Carlos: PPG-ERN/UFSCar. 229 p.

TUPINAMBÁS, TH., CALLISTO, M. and SANTOS, GB. 2007. Benthic Macroinvertebrate assemblage structure in two headwather streams, south eastern, Brazil. Revista Brasileira de Zoologia, vol. 24, no. 4, p. 887-897. http://dx.doi.org/10.1590/S010181752007000400005

VANNOTE, RL., MINSHALL, GW., CUMMINS, KW., SEDELL, JR. and CUSHING, CE. 1980. The river continuum concept. Canadian Journal of Fisheries and Aquatic Sciences, vol. 37, no. 1, p. 130137. http://dx.doi.org/10.1139/f80-017

Received: 20 January 2014 Accepted: 08 July 2014 